\title{
Are Viatical Settlements Securities Within the Regulatory Control of the Securities Act of 1933?
}

\author{
Shanah D. Glick $\dagger$
}

In the past five years, a new market has arisen that affords terminally-ill persons, frequently AIDS patients in the last eighteen to twenty-four months of life, access to needed financial resources. These transactions, known as viatical settlements, function in the following manner. Upon certification of the patient's medical condition, she assigns ownership of her life insurance policy to the buyer. The buyer then names herself as the new beneficiary of the policy. As payment for the right to future life insurance proceeds, the buyer advances to the seller fifty to eighty percent of the face value of the policy. The buyer usually pays the designated purchase price immediately in one lump-sum amount, although occasionally the seller requests a short-term payment stream. ${ }^{1}$

The companies active in this new market fall into one of two categories. First are those companies, capitalized through either private funds or the sale of company stock, that purchase the life insurance policies directly from patients. These companies are the ultimate buyers of the policies; they hold all rights to the policies through either complete ownership or assignment, and they are the new named beneficiaries of the policies. ${ }^{2}$ Because these companies purchase policies directly, these transactions will be referred to as non-brokered viatical settlements. Second, some companies act as brokers or middlemen by matching a potential buyer or group of buyers with a particular policy currently "on the market." The buyer purchases the rights under the policy, naming herself the new beneficiary. The broker never assumes ownership and instead receives payment in return for services rendered. ${ }^{3}$ These transac-

$\dagger$ A.B. 1990, Princeton University; J.D. 1993, The University of Chicago.

${ }^{1}$ Richard Bandfield, Viatical Settlements: An Important New Insurance Option 1-2 (Pamphlet prepared by Bandfield Associates, Oct 21, 1992) (on file with U Chi L Rev).

2 States Probe Life Insurance Schemes: Firms Prey on AIDS Patients, Chi Trib C3 (Aug 20, 1992).

${ }^{3}$ Bandfield, Viatical Settlements at 3. 
tions will be referred to as brokered viatical settlements. To date, at least one state securities commissioner has decided to treat brokered viatical settlements as securities. ${ }^{4}$ This Comment considers whether either type of settlement is a security under the Securities Act of 1933 ("the '33 Act").

Section I of this Comment examines the application of the '33 Act to viatical settlements, discussing both the Act's definition of a security and its exemption for contracts of insurance. ${ }^{5}$ Section II argues that viatical settlements are not insurance because, while they involve the sale of an insurance policy, the transaction nevertheless lacks the characteristics that define an insurance or general indemnification contract. Section III argues that viatical settlements are not securities either under the "investment contract" language of the '33 Act, ${ }^{6}$ as interpreted by the Supreme Court in SEC $v$ Howey Co., ${ }^{7}$ or under a functional analysis of the transactions. Critically, the finding that viatical settlements do not comport with our basic functional understanding of a security helps to explain the tensions that become apparent in the application of Howey. This Comment concludes that, whether brokered or nonbrokered, viatical settlements are not securities and therefore are not subject to the regulatory control of the '33 Act.

\section{IntRoduction to the SEcurities Act of 1933}

It is commonly and correctly stated that the '33 Act is not a comprehensive, federal, anti-fraud regulation of all financial transactions..$^{8}$ The '33 Act was instead "intended to encourage 'honest dealing in securities and thereby bring back public confidence' in the investment markets." ${ }^{\circ}$ The '33 Act regulates the public offering of securities in an attempt to protect investors from fraud. ${ }^{10}$

- In August 1992, Glenn Pomeroy, the Securities Commissioner of North Dakota, issued cease-and-desist orders against two viatical settlement brokers on the grounds that the companies were engaged in the unregistered sale of securities. Peter Kerr, Now, AIDS Patients' Lives Are Drawing Speculators, NY Times A1 (Aug 20, 1992); States Probe Life Insurance Schemes, Chi Trib at C3 (cited in note 2). .

${ }^{5}$ Securities Act of 1933,15 USC $\$ \$ 77 b(1), 77 c(a)(8)$ (1988). These sections will be referred to as $\S \S 2(1)$ and $3(a)(8)$ respectively for the remainder of this Comment.

- 15 USC $\S 77 \mathrm{~b}(1)$.

328 US 293, 298-99 (1946).

${ }^{8}$ See, for example, Reves v Ernst \& Young, 494 US 56, 61 (1990), citing Marine Bank v Weaver, 455 US 551, 556 (1982).

- Gary Plastic Packaging Corp. v Merrill Lynch, Pierce, Fenner \& Smith, Inc., 756 F2d 230, 237 (2d Cir 1985), quoting Letter from President Franklin D. Roosevelt to Congress (March 29, 1933), in 77 Cong Rec 937 (1933) (emphasis added).

${ }^{10}$ See Ernst \& Ernst v Hochfelder, 425 US 185, 195 (1976). 
Transactions involving investments other than securities, and even some particular types of securities, are excluded from the '33 Act's coverage. ${ }^{11}$

The '33 Act's regulatory structure is relatively straightforward. If an investment fulfills the '33 Act's definition of a security and has not been specifically exempted from compliance with the Act's provisions, the issuer of that security must comply with specific disclosure requirements before proceeding with the public offering. ${ }^{12}$ This regulatory regime poses two questions: Is the instrument a security? Is the instrument expressly exempt from the regulatory control of the '33 Act?

Among the instruments expressly excluded from the '33 Act's definition of "security" are insurance policies. Section 3(a)(8) of the Act provides:

the provisions of this subchapter shall not apply to any of the following classes of securities: Any insurance or endowment policy or annuity contract or optional annuity contract, issued by a corporation subject to the supervision of the insurance commissioner, bank commissioner, or any agency or officer performing like functions, of any State or Territory of the United States or the District of Columbia. ${ }^{13}$

Actually, the language of $\S 3(\mathrm{a})(8)$ is misleading. The ' 33 Act implies that insurance contracts are securities and that, were it not for the exemption, they would be subject to the '33 Act's provisions. This is not true. As this Comment will establish, insurance contracts are not securities. They are wholly outside of the '33 Act. Justice Brennan wrote in his concurring opinion in SEC $v$ Variable Annuity Co.: "[I]t would appear that in the case of the ordinary insurance policy, the exemption would be just confirmatory of the policy's noncoverage under the definition of security."14 The ex-

11 See, for example, the exemption of securities issued or guaranteed by the United States government in $\S 3(\mathrm{a})(2)$, the exemption for securities which are part of an intrastate offering in $\S 3(\mathrm{a})(11)$, and the exemption of notes with a maturity of less than 9 months in $\S 3(a)(3) .15$ USC \& $77 \mathrm{c}(\mathrm{a})(1988)$.

12 James Cox, Robert Hillman, and Donald Langevoort, Securities Regulation 215 (Little, Brown \& Co., 1991).

1515 USC $\S 77 \mathrm{c}(\mathrm{a})(8)$. This section exempts both life insurance policies and annuities. For a discussion of the relevance of the annuity exemption to viatical settlements, see text accompanying notes $27-29$.

14 359 US 65, 74 n 4 (1959) (Brennan concurring), citing HR Rep No 85, 73d Cong, 1st Sess 15 (1933). 
emption is "clearly supererogation";1s it is superfluous because even without the exemption insurance is not a security. Nonetheless, the '33 Act expressly excludes insurance from its definition of a security.

This Comment will first consider whether viatical settlements are contracts of insurance, and thus exempt from the ' 33 Act under $\S 3(\mathrm{a})(8)$. If viatical settlements are contracts of insurance, it is irrelevant whether they are securities. The securities law would not apply due to the exemption for contracts of insurance. If, on the other hand, viatical settlements are not contracts of insurance, that conclusion does not resolve whether or not the settlements are securities. Because this Comment concludes that viatical settlements are not insurance contracts, it proceeds to consider whether they are securities.

\section{Are Viatical Settlements "Contracts of Insurance"?}

Although viatical settlements are relatively new transactions, the assignment of life insurance policies has long been permitted. ${ }^{16}$ Nevertheless, courts have not addressed the issue of whether an assignment of a life insurance policy is a security under the '33 Act. This Section, therefore, analyzes an open question in considering whether viatical settlements, a special class of life insurance assignments, are securities. Subsection A describes two fundamental characteristics of insurance policies. Subsection B shows how the Supreme Court has used a functional analysis that focuses on these characteristics to determine whether annutities fall with the '33 Act's insurance exemption. Subsection C extends that func-

1s Tcherepnin $v$ Knight, 389 US 332, 342 n 30 (1967); see also Grainger $v$ State Sec. Life Ins. Co., 547 F2d 303, 305 n 6 (5th Cir 1977).

16 "[A]lthough an insurable interest is necessary where a would-be-beneficiary applies to insure someone else's life, public policy does not prohibit a good faith assignment or transfer of a life insurance policy previously issued to one without an insurable interest." In re Butcher, 72 BR 240, 244 (E D Tenn 1987), citing Clement $v$ New York Life Insurance Co., 101 Tenn 22, 36, 46 SW 561, 564 (1898). The rationale behind this policy is that a beneficiary of a life insurance policy does not need an insurable interest at the time of death in order to receive the proceeds of a policy. In re Al Zuni Trading, Inc., 947 F2d 1403, 1405 (9th Cir 1991) ("[T]he almost universal rule of law in this country is that if the insurable interest requirement is satisfied at the time the policy is issued, the proceeds of the policy must be paid upon the death of the life insured without regard to whether the beneficiary has an insurable interest at the time of death."), quoting Secor v Pioneer Foundry Co., 20 Mich App 30, 34-35, 173 NW2d 780, 782 (1970). The majority of courts and legal scholars decided there was no logic to requiring insurable interests for assignees but not beneficiaries and abandoned assignment restrictions as meaningless formalities. Robert Keeton and Alan Widiss, Insurance Law: A Guide to Fundamental Principles, Legal Doctrines, and Commercial Practices $\$ 3.5(d)$ at 186 (West, 1988). This Comment adopts the majority view. 
tional analysis to viatical settlements and concludes that they do not fall within the insurance exception.

\section{A. Insurance Characteristics: Risk-Transfer and Risk-Spreading}

Although there is much disagreement concerning the definition of a security, an instrument's classification as a standard insurance policy does not give rise to similar problems. A true contract of insurance both transfers risk and distributes (or spreads) risk. ${ }^{17}$ In the case of the most straightforward life insurance policy (a policyholder insuring her own life), the insured knows that at an unspecified date in the future she will die and the risk of financial loss occasioned by her death (loss of income or services) will be realized. The insured transfers this risk, or at least a portion of the risk, to the insurer, who assumes the risk by agreeing to compensate the insured's estate or a designee for a pre-determined sum that is theoretically no more than the aggregate financial loss resulting from the insured's death. ${ }^{18}$ The life insurance policy is the contractual obligation that transfers this risk. By the terms of the contract, the insured pays the third party actuarially-derived premiums to assume this risk. Thus, the premiums are the price of the risk-transferral.

From the insured's point of view, the success of the risk-transferral depends upon the payment of premiums and the solvency of the insurer. Unlike an investment, the rate of return on an insurance policy does not depend upon how the insurer employs the money paid (the premiums). The insurer has categorically and unqualifiedly agreed to compensate the insured upon the realization of a contractually-defined risk.

The concept of risk-distribution or risk-spreading enables insurance companies to assume their clients' risks through a pooling technique. Again, concerning ourselves with only standard life in-

17 Keeton \& Widiss, Insurance Law § 1.2 at 6; Kenneth Abraham, Insurance Law and Regulation 2 (Foundation Press, 1990). Professor Abraham identifies a third characteristic of insurance, risk-allocation, which focuses on the insurance company's risk pricing mechanism-the relationship of risk levels to premiums charged. Id. Because this factor bears on the internal mechanics of insurance companies, it may be ignored for purposes of this Comment.

1s Even in insuring one's own life, one is bound by the formal logic that, because insurance is strictly compensatory, one cannot insure one's life for more than the loss which will be occasioned by death. In order to avoid the difficulty, if not moral distaste, of economically evaluating a person's life, we generally employ the legal fiction that this interest is unlimited because human life is of infinite value. Keeton \& Widiss, Insurance Law $\S 3.5(\mathrm{~b})(1)$ at $178-79$. 
surance policies, the insurance company knows that each individual risk will be realized at some uncertain date in the future. The company sets prices based on statistical models, which will underestimate the actual costs in some cases and will overestimate the actual costs in others. By the law of averages, if an insurance company extends coverage to enough people, the risks should net out, and the insurance company will not face overexposure. Pooling thus minimizes insurance companies' net exposure to risk.

Not only do securities lack the elements of risk-transferral and risk-spreading, but life insurance also lacks the central and perhaps the one undisputed characteristic of a security: the pursuit of profit. $^{19}$ From the policyholder's point of view, insurance is not a profit-driven transaction. The doctrine of insurable interest establishes that insurance cannot be undertaken for wagering (profitseeking) purposes. ${ }^{20} \mathrm{~A}$ person cannot insure property in which she does not have an identifiable interest. ${ }^{21} \mathrm{~A}$ merchant can insure her delivery truck, but she cannot insure her competitor's delivery truck. If her truck is destroyed, she will lose both the truck and any business dependent on the truck. Insurance proceeds would compensate her for a realized risk. But if her competitor's truck is destroyed, she suffers no loss, because she had an interest in neither the truck itself nor in its routes. Any money realized on the destruction of the competitor's truck would be profit-the successful realization of a gambling proposition..$^{22}$

19 The pursuit of profit is a fundamental characteristic of a security. The Court has established that a scheme is an "investment contract," and therefore a security, if it "involves an investment of money in a common enterprise with profits to come solely from the effort of others." Howey, 328 US at 301 (emphasis added).

${ }^{20}$ See, for example, Warnock \& Davis, 104 US 775, 779 (1881) (life insurance policies not based on an insurable interest are wagers, and therefore against public policy); Aetna Casualty \& Surety Co. v Davidson, 715 F Supp 775, 777 (S D Miss 1989) (same); New York Life Insurance Co. v Baum, 700 F2d 928, 934 (5th Cir 1983) (same); Prince v Royal Indemnity Co., 541 F2d 646, 649 (7th Cir 1976) (same), quoting Womble v Dubuque Fire \& Marine Insurance Co., 310 Mass 142, 147, 37 NE2d 263 (1941). This point regarding the initial procurement of insurance, however, should not be understood to "preclude the [later] assignments of life insurance contracts." Keeton \& Widiss, Insurance Law § 3.5(b)(2) at 180 (cited in note 16). See text accompanying note 23.

${ }^{21}$ See, for example, Omaha Property and Casualty Co. $v$ Crosby, 756 F Supp 1380, 1384 (D Mont 1990); In re Triangle Door and Truss Co., 41 BR 164, 169 (E D Tenn 1984); Davidson, 715 F Supp at 776.

${ }^{22}$ The insurable interest doctrine attempts not only to prohibit profit-seeking through insurance, but also to prevent the intentional destruction of property for the purpose of collecting insurance proceeds. Keeton and Widiss, Insurance Law $\$ 3.1(\mathrm{c})$ at 138. If a person has no interest in or connection to property or a life, and that person insures the property or life against a risk, then that person has an incentive to cause the realization of the risk. Normally, if a person has an insurable interest in the insured property or life, not only 
Likewise, a person can only insure another person's life if she stands to suffer loss from that person's death..$^{23}$ Outside the family context, a person can assume insurance on the life of another if, through a "pecuniary" relationship, she expects to receive "some benefit or advantage from the continuance of the life of the assured."24 This pecuniary relationship exists when, for example, the assured is a debtor, a business partner, or a key employee of the insurer. ${ }^{25}$ Even within the context of family relations, the purchaser has a sufficient insurable interest only if, because of "blood or affinity," she benefits from the continued life of the assured. ${ }^{26}$

\section{B. The Supreme Court's Functional Analysis}

In determining whether particular annuities are excluded from the definition of "security" under $\S 3(\mathrm{a})(8)$ of the '33 Act, the Supreme Court employed a functional analysis that can be extended to viatical settlements. SEC $v$ Variable Annuity $\mathrm{Co}^{27}$ and SEC $v$ United Benefit Insurance $\mathrm{Co}^{28}$ presented the question of whether non-traditional annuities, which attempt to hedge inflation risks by tying the annuity payment to the value of the market pool in which the funds were invested, were securities under the '33 Act. In each case, the Court focused on the functional characteristics of the annuity as a form of insurance. In Variable Annuity, the Court stated that the annuity in question lacked "true underwriting of risks, the one earmark of insurance as it has commonly been conceived of in popular understanding and usage."28 Because the value

is the incentive not present, but that person is actively deterred from purposeful destruction of the property or life. The person either has a financial self-interest in the everyday operating proceeds of the insured property or the person has a financial and/or emotional selfinterest in the continuation of the insured life. In the absence of an insurable interest, neither these self-interests nor the deterrent effect they normally create are present. Thus, by mandating the existence of an insurable interest, the doctrine attempts to prevent such socially wasteful and typically criminal activity as the purposeful destruction of property or life. Id.

${ }^{23}$ Keeton and Widiss, Insurance Law $\S 3.5$ (a) at 179 (cited in note 16); see also Rubenstein v Mutual Life Ins. Co. of New York, 584 F Supp 272, 278 (E D La 1984).

24 Warnock, 104 US at 779.

25 Keeton \& Widiss, Insurance Law § 3.5(c)(3) at 183 (cited in note 16); see also Rubenstein, $584 \mathrm{~F}$ Supp at $274 \mathrm{n} 1$ (differentiating between credit life insurance in which the "insurer risks that the debtor-insured will die before he can repay the creditor-beneficiary an existing debt" and "key man" business insurance in which "the insurer risks the death of someone whose loss would be highly detrimental to the business"); Baum, 700 F2d at 934 (creditor has insurable interest in life of the debtor).

26 Warnock, 104 US at 779.

27359 US 65 (1959).

387 US 202 (1967).

20 359 US at 73 (footnote omitted). 
of the annuity hinged on the performance of the investment pool, all risk was placed on the annuitant and none on the issuing company. ${ }^{30}$ Moreover, the mortality risk assumed by the issuing company was only an "apparent" and "superficial" "aspect of insurance." 31 The annuity lacked the functional characteristic of risktransferral, and therefore, the Court held that the fund no longer qualified for statutory exemption from the federal securities regulation. ${ }^{32}$

In United Benefit, the Court again adopted this functional analysis, determining that a Flexible Fund contract was not an optional annuity contract within the '33 Act's $\S 3(\mathrm{a})(8)$ exemption. ${ }^{33}$ Responding to Variable Annuity, the Flexible Fund marketers offered an annuity with a market rate of return but which also contained a guaranteed payment portion which would place some investment risk on the issuing company in the hope of retaining exempt annuity status. The Court, in turn, responded by deconstructing the Flexible Fund into two distinct promises: the payment of a guaranteed minimum annuity amount and the payment of a variable amount, tied to the performance of the investment pool. ${ }^{34}$ The Court found that, although the guaranteed payment did reduce "substantially the investment risk of the contract holder, the assumption of an investment risk cannot by itself create an insurance provision under the federal definition." 36 Under a functional analysis, the Flexible Fund did not qualify for exemption under $\S 3(\mathrm{a})(8) .{ }^{36}$

\section{Application of Functional Analysis to Viatical Settlements}

Based upon Variable Annuity and United Benefit, if viatical settlements do not serve a risk-transferring or risk-spreading function, or do so to a superficial or insignificant degree, the settlements cannot be properly identified as exempt insurance contracts under $\S 3(\mathrm{a})(8)$. This functional analysis therefore turns on the mechanics of viatical settlements.

In a viatical settlement, the policyholder assigns all ownership rights to a third party in return for a fixed sum of money. This

\footnotetext{
so Id at 71.

31 Id.

32 Id.

ss 387 US at $210-11$.

34 Id at 209.

ss Id at 211, citing Helvering $v$ Le Gierse, 312 US 531, 542 (1941).

ss United Benefit, 387 US at 211.
} 
sum reflects the buyer's estimation of the present value of the policy's future money claim, discounted by both the premiums the buyer expects to pay and the risk that the seller will live longer than expected. After purchasing the policy, the buyer steps into the shoes of the former owner. The buyer assumes the right to name the beneficiary of the policy, a power she will exercise in her name to recoup the purchase price and to earn a return on the investment. ${ }^{37}$ Most critically, because the buyer pays the purchase price to the original owner, but receives later payment from the insurance company, the return on the buyer's investment does not depend on how the seller uses the proceeds from the sale.

In light of the mechanics of viatical settlements, the question of whether the settlements sufficiently serve the functions required to qualify for the insurance exemption seems to have a clear answer: no. First, the viatical settlement cannot qualify for statutory exemption by virtue of the fact that its underlying asset, an insurance policy, is itself exempt. As noted in SEC $v$ Joiner regarding the definition of a security under the '33 Act, "the courts have not been guided by the nature of the assets back of a particular document or offering."38 The transaction must be analyzed on its merits, not on the nature of its underlying asset.

Second, the viatical settlement transaction itself does not qualify as a form of insurance. ${ }^{39}$ The settlements neither transfer nor distribute risk; they are therefore not contracts of insurance.

s7 Just like buying stock for another person's benefit, the buyer could plausibly name another person as the beneficiary. Such a designation would alter neither the investment character of the transaction nor the profit expectation of the buyer.

ss 320 US 344, 352 (1943) (assignment of oil leases was a security under the ' 33 Act). As examples, the Court cited, among other cases, SEC $v$ Crude Oil Corporation of America, 93 F2d 844, 848 (7th Cir 1937) (bills of sale for barrels of oil were securities) and SEC $v$ Bailey, 41 F Supp 647, 651 (S D Fla 1941) (sale of land to be developed for the commercial cultivation of tung trees held to be a security). For more recent examples, see also Olson $v$ E.F. Hutton \& Co., Inc., 957 F2d 622, 628-29 (8th Cir 1992) (brokers' unnecessary buying and selling of certificates of deposit may bring CDs within federal securities law); Gary Plastic Packing Corp. v Merrill Lynch, Pierce, Fenner \& Smith, Inc., 756 F2d 230, 240 (2d Cir 1985) (certificates of deposits sold by investment firm were securities).

30 Although $\S 3(\mathrm{a})(8)$ exempts both insurance and annuity contracts, this Comment will focus only on the insurance exemption. Viatical settlements assign pre-existing exempt life insurance policies, not pre-existing exempt annuities. Furthermore, in the typical annuity, the annuity issuer promises to pay the annuitant a specified annual sum, commencing upon a certain date in the future. The annuitant pays to the annuity issuer either a lumpsum premium, annual premiums for a specified duration, or a combination of the two. When the money is later "returned" through the annuity payments, one of the two parties bears the cost of having incorrectly estimated the annuitant's life expectancy.

A viatical settlement is not an annuity because the selling policyholder does not assume the risk that she will die sooner than expected. The policyholder/seller receives her money 
Variable Annuity teaches that, in determining whether an instrument fulfills the functional insurance requirement of risktransferral, both the buyer's and the seller's post-transaction positions must be examined. Effective risk-transferral demands particular actions and outcomes by both parties to an insurance or annuity transaction. The insured must have actively transferred a risk and the insuring party must have actively assumed that same risk. The Court in Variable Annuity found that the instruments in question were not annuities because the annuitant (analogous to a seller in a viatical settlement) had not effectively transferred any risk to the insurance company (analogous to a buyer in a viatical settlement). ${ }^{40}$ Only by scrutinizing both parties to the transaction was the Court able to conclude that "the variable annuity places all the investment risks on the annuitant, none on the company."11

Upon examining both the buyer's and the seller's post-transaction positions, it is clear that viatical settlements do not exhibit any insurance functions or characteristics. The seller does not attempt to insure against the realization of a future risk; hence, there is no risk-transferral. The seller attempts to gain either disposable income to fulfill a last wish or needed financial resources for present expenses. ${ }^{42}$ In the first case, the seller is concerned not with protecting against future risk but with present enjoyment through consumption. In the second case, the seller has already realized a risk, that of insolvency. Her actions are an ex post response, not an ex ante measure of protection. Although the insured previously

up front and in a predetermined amount. Although the viatical settlement buyer will profit from the policyholder's early 'death, the policyholder, unlike the annuitant, does not incur a financial loss by dying sooner than calculated, thus not recouping all of her invested funds. Regardless of her date of death, she receives the same compensation. The characteristic risk element of an annuity with regard to the annuitant has therefore been eliminated.

Similarly, the characteristic risk element of an annuity with regard to the issuer has also been eliminated. The buyer in a viatical settlement does not assume the risk of extended payment that is the basis of an annuity. The fact that, just as in an annuity, the buyer's profit will ultimately turn on the date of the insured's death is not sufficient to transform a viatical settlement into an annuity. The insured's date of death marks the maturity of a financial investment, not the end of an annuity.

10359 US at 71.

11 Id (footnote omitted).

42 A recent informal survey conducted by the National Association of People with AIDS (NAPWA) of 1800 people living with HIV or AIDS found that when "[a]sked to rank their greatest needs, an overwhelming number cited financial assistance. Nearly three out of 10 respondents live on less than $\$ 500$ a month, and another three in 10 live on between $\$ 500$ and $\$ 1000$ a month." Among those fully employed, 32\% stated they lacked health care and medicine, and $16.7 \%$ stated they needed access to adequate health care. NAPWA, Surprising Results From First-Ever National Needs Assessment: Violence, Discrimination, Poverty Common Problems, Living HIV 5 (Fall 1992) (on file with U Chi L Rev). 
transferred the risk of financial loss occasioned by death, she did not transfer the risk of general insolvency, of financial loss through major illness, or of any pre-death loss. In sum, the seller does not seek to and is not involved in a risk-transferral activity. If anything, she is dissipating any risk-transferral she previously undertook.

Similarly, the buyer does not act as an insurer. The buyer neither assumes a risk from the seller nor spreads any risk. The buyer does not accept a transferred risk because the seller does not transfer a risk. The buyer does assume the investment risk that the seller will not die soon enough for the buyer to realize a market-or at least a positive-rate of return on her money. The seller, however, does not transfer this risk to the buyer. The risk is created voluntarily by the buyer through her actions in purchasing the policy. It is incidental that this investment risk flows from the payout on a life insurance policy.

Second, the buyer neither spreads nor distributes risk-even when she diversifies her viatical settlement portfolio by purchasing numerous policies. Because the buyer assumes no risk from the seller, she cannot spread or distribute such a risk. As for purchases of numerous policies, the buyer is lessening her exposure to selfcreated investment risk, not spreading risk from the buyer. Only the insurance company continues to spread the risk of loss occasioned by the seller's death.

Neither does the buyer create a short-term insurance policy on the seller's life. Unlike the creditor who insures her debtor's life, the buyer has no pre-transaction financial interest in the seller. The interest arises only after and explicitly on account of the transaction. Even if the alleged purpose of the transaction were to insure the life of the seller, it would be invalid under the doctrine of insurable interests. ${ }^{43}$

Viatical settlements do not transfer or distribute risks even though the asset underlying the transaction fulfills both functions. Thus, as the American Council of Life Insurance has concluded, viatical settlements are not instruments of insurance. ${ }^{44}$ The following example should dispel any remaining belief that viatical settlements might be insurance contracts.

4s See text accompanying note 20 .

4 Colleen Mulcahy, Viatical Settlement Dispute Flares, National Underwriter, Life and Health/Financial Services Edition 3 (Sep 7, 1992), available on NEXIS (INSURE Library, NULIFE File). 
Suppose Seller owns a U.S. Treasury note. ${ }^{45}$ She is willing to sell it, but she will not reveal any information regarding its maturity date, except for the fact that there is a high probability that the Treasury note will mature within two years. ${ }^{46}$ Seller also informs Buyer that an annual servicing fee must be paid to the third party from whom she originally purchased the note. If Buyer wishes to purchase, Buyer will discount the face value of the note in light of her estimation of the maturity date, the annual servicing fees that must be paid until that date, and the risk contained in the uncertainty about the maturity date. This discounted sum will be the purchase price of the Treasury note.

This is the essence of a viatical settlement, yet a Treasury note has been substituted for the life insurance policy. The transaction in both cases is driven by a third party's promise to pay a fixed sum of money in the future. Whether the third party is the United States government or a life insurance company is irrelevant. The investor looks only for certainty of repayment. The fundamental characteristics of the investment transaction cannot be mistaken for those of the asset backing the investment.

Viatical settlements are not contracts of insurance; they neither transfer nor distribute risk. As such, they are not eligible for a $\S 3(\mathrm{a})(8)$ statutory exemption. Yet, they are not thus automatically rendered securities; they are only securities if they fall within the definition of "security" in the '33 Act.

\section{Are Viatical Settlements Securities?}

A. The Definition of a Security

Section 2(1) of the '33 Act defines a "security" as

any note, stock, treasury stock, bond, debenture, evidence of indebtedness, certificate of interest or participation in any profit-sharing agreement, collateral-trust certificate, preorganization certificate or subscription, transferable share, investment contract, . . . or, in general, any interest or instrument commonly known as a "security" . . . .77

In line with the remedial goals of the statute, the definition is broad and comprehensive, although, as noted before, not all-inclu-

\footnotetext{
45 A Treasury note is an obligation of the federal government that has a maturity of one to five years.

46 Most viatical settlement companies "will not consider viatication if the insured has a life expectancy of more than 2 years." Bandfield, Viatical Settlements at 9 (cited in note 1).

47 USC \& $77 \mathrm{~b}(1)$.
} 
sive. Recognizing the "countless and variable schemes devised by those who seek the use of the money of others on the promise of profits," inition unorthodox and innovative investments that nevertheless are securities. The "investment contract" language of $\S 2(1)$ was designed to fulfill this function, and it has largely succeeded in doing so. ${ }^{49}$ Given their novel and unorthodox nature, if viatical settlements are securities, it is because they fit within the "investment contract" language of $\S 2(1)$. The assignment of a life insurance policy does not fit any of the other $\S 2(1)$ enumerations of a security.

\section{B. The Howey Test}

The Supreme Court established the definition of an investment contract in SEC $v$ Howey Co. ${ }^{50}$ a case in which the Court found that the offering and sale of orange groves in connection with a service contract constituted a security under the investment contract language of the '33 Act. To repeat oft-quoted language, the Court stated that the "test is whether the scheme involves an investment of money in a common enterprise with profits to come solely from the effort of others."

Howey has been distilled into a four-prong test. The test requires: 1) an investment of money, 2) that the investment be undertaken with the expectation of profit, 3 ) that the profits are derived solely from the effort of others, and 4) the existence of a common enterprise. Although it is uniformly accepted that an instrument must satisfy all elements of the test to be a security, ${ }^{52}$ the requirements necessary to satisfy the third and fourth prongs have been the subject of considerable controversy. Instead of choosing among the competing interpretations of the Howey test, this Com-

48 SEC v Howey Co., 328 US 293, 299 (1946).

49 See, for example, Miller $v$ Central Chinchilla Group, Inc., 494 F2d 414, 417 (8th Cir 1974) (chinchilla farming scheme found to involve the sale of a security); Smith $v$ Gross, 604 F2d 639, 643 (9th $\mathrm{Cir}$ 1979) (earthworm breeding scheme found to involve sale of a security); SEC v Aqua-Sonic Products Corp., 687 F2d 577, 585 (2d Cir 1982) (franchise scheme involving dental equipment was a security).

so 328 US 293 (1946).

s1 Id at 301.

s2 See, for example, In re EPIC Mortgage Insurance Litigation, 701 F Supp 1192, 1248 (E D Va 1988), citing Burton v Heinhold Commodities, Inc., 646 F Supp 360, 361 (E D Va 1986) (if any one of the four requirements of Howey is not met, the instrument is not a security). 
ment will analyze viatical settlements under all existing interpretations.

With respect to the first three requirements of the Howey test, this Comment will analyze both brokered and non-brokered viatical settlements together. Application of the last Howey requirement (the common enterprise requirement), however, requires separate analysis of brokered and non-brokered transactions due to the factual variations between the two transactions.

1. Brokered and non-brokered settlements under the first three prongs of Howey.

First, Howey requires an "investment of money." An individual invests money if she commits assets in such a way that she is subject to financial loss. ${ }^{53}$ In either a brokered or a non-brokered viatical settlement, the investor, whether an individual or a company, commits cash assets by purchasing the life insurance policy. The investor also subjects herself to the risk of financial loss. If the seller lives longer than expected, the buyer might receive either a below-market or a negative rate of return on her investment, thereby realizing a financial loss. Thus, both brokered and nonbrokered viatical settlements satisfy the first prong of the Howey test.

Second, Howey requires that the investor have an "expectation of profit." In United States Foundation, Inc. $v$ Forman, ${ }^{54}$ the Court held that shares of stock in a state-subsidized nonprofit housing cooperative were not securities because the "investors were attracted solely by the prospect of acquiring a place to live, and not by financial returns on their investments." not reside in the housing cooperative without purchasing a specified minimum number of shares, and only qualifying prospective tenants could purchase the stock. ${ }^{56}$ The Court therefore found that stock purchasers were motivated not by a profit-motive but by reasons of personal consumption and use. The purchasers had not parted with their "money in the hope of receiving profits";s7 rather, they had parted with their money in the hope of receiving housing accommodations. Whatever "profits" that may have been

ss Hector $v$ Wiens, 533 F2d 429, 432 (9th Cir 1976), citing El Khadem v Equity Securities Corp., 494 F2d 1224 (9th Cir 1974).

s4 421 US 837 (1975).

ss Id at 853.

${ }^{88}$ Id at $842-43$.

${ }^{37}$ Id at 858. 
generated through tax deductions, below-market rental fees, or income derived from leasing cooperative space to commercial entities, were "too speculative or insubstantial" to supplant the primary consumption motivation of the purchasers. $^{.8}$ To be an expectation, financial profits must be a substantial motivation of the investor.

Buyers of brokered and non-brokered settlements invest with the expectation of profit. ${ }^{5 \theta}$ Solicitation material for one brokered settlement firm urged: "Enclosed is a real innovative MONEY MAKER you really need to pursue . . . . The average investor return is better than $20 \%$ annually." ${ }^{\text {"0 }}$ Moreover, it is highly improbable that an individual would lay out thousands of dollars of personal funds to an unrelated third party at substantial risk to herself if she were not expecting financial gain. Furthermore, the existence of a $\$ 100$ million high-risk, high-return market suggests that investors are motivated by the expectation of profit. Indeed, industry participants acknowledge their own profit incentives. The partner of one non-brokered viatical settlement company stated, "I would say there's a lot of money involved [in viatical settlements]. It's a handsome return. There are no [other] good investments out there." Council of Life Insurance, have noted that "there is a tendency for [viatical settlement firms] to take large profits."

While viatical settlement companies might be partly motivated by desire to help terminally-ill patients meet their financial obligations, this alone will not bring the settlements outside the scope of Howey. It is not enough that investors have altruistic motives if they are also motivated by the expectation of profit. Under Forman, it is only when the expectation of profit is too speculative or insubstantial to be a motivating factor that this prong of Howey is met. Viatical settlement companies have not sought the tax-free charity status most appropriate for a purely humanitarian venture. Nor do they target their investment returns to cover only costs and

6s Forman, 421 US at 856; see also Grenader v Spitz, 537 F2d 612, 618 (2d Cir 1976) (sale of stock in privately-owned housing cooperative was not a security because "the profit motive, if any, was purely incidental").

30 The average viatical settlement investor expects at least a 15 percent return on the investment. Telephone interview with Richard Bandfield, Financial Counselor, Bandfield \& Drivanos (Nov 4, 1992). 1992).

co Letter from Joe Sowell, President, National Insurance Marketing, Inc. (July 10,

61 New Firms Cashing in on AIDS Patient's Insurance, LA Bus J 1 (Aug 31, 1992).

2 Mulcahy, Viatical Settlement Dispute Flares at 3 (cited in note 44). 
a small profit; the fifteen percent return expected ${ }^{63}$ is more consistent with a risk-capital venture than a humanitarian enterprise.

The third prong of Howey requires that profits derive "solely from the efforts of others." In applying this prong, the courts have not adhered to a literal interpretation of the word "solely." In SEC $v$ Glenn W. Turner Enterprises, Inc., ${ }^{84}$ the Ninth Circuit held that this prong of Howey is satisfied whenever "the efforts made by those other than the investor are the undeniably significant ones." investor participation in the activity would unreasonably deny the investor the protection of the securities law. ${ }^{66}$ As the court in SEC $v$ Koscot Interplanetary, Inc. declared, such "[a] literal application of the Howey test would frustrate the remedial purposes of the Act." ${ }^{67}$ In Forman, the Supreme Court took notice of the Ninth Circuit's interpretation, but declined to comment directly on it. ${ }^{68}$ Nevertheless, the Court implicitly endorsed a more flexible interpretation of "solely" when it stated that "the touchstone [of the definition of a security] is the presence of an investment in a common venture premised on a reasonable expectation of profits to be derived from the entrepreneurial or managerial efforts of others." ${ }^{\prime 2}$ By altering the traditional language of Howey, the Supreme Court identified that its concern was not that only others advance efforts toward profit realization, but that others advance significant efforts (managerial or entreprenuerial) from which profits will stem. In the wake of Forman, most lower courts have followed the Ninth Circuit's lead, applying the third prong of Howey liberally. ${ }^{70}$

Neither brokered nor non-brokered viatical settlements satisfy either the liberal or the literal version of the "solely from the efforts of others" test. To satisfy this test, both the "other" whose effort produces profits and the effort itself must be identified. Two possible "others" exist: the policy seller and the viatical settlement broker.

\footnotetext{
63 Telephone interview with Richard Bandfield (cited in note 59).

of 474 F2d 476, 482 (9th Cir 1973).

es Id. See also SEC v Murphy, 626 F2d 633, 641 (9th Cir 1980) (because the investors had no managerial role whatsoever, the contract was a security under Howey); Hector, 533 F2d at 433 (critical inquiry is who controlled the firm's "essential managerial efforts").

${ }^{68}$ Glenn Turner, 474 F2d at 482 (noting it would be easy to evade such a strict interpretation).

${ }^{67} 497$ F2d 473, 480 (5th Cir 1974).

68 421 US at $852 \mathrm{n} 16$.

${ }^{69}$ Id at 852 (emphasis added).

${ }^{70}$ Cox, Hillman, and Langevoort, Securities Regulation at 137 (cited in note 12).
} 
The policy seller's efforts do not satisfy the profits "solely from the efforts of others" requirement. Putting aside concerns of insurance company solvency, the investor's profits depend on two factors: the initial sale of the assignment and the ultimate date of death of the seller. The seller's efforts regarding the sale can be subdivided into promotional efforts and price setting. The seller's promotional efforts are insufficient to qualify as third-prong Howey efforts, and her price-setting efforts actually counteract the buyer's potential for profit realization.

The seller promotes a viatical settlement by initiating contact with a buyer or broker and actively pursuing the transaction. These efforts, however, do not satisfy the requirements of either the liberal or the literal interpretations of Howey. Howey looks for "entrepreneurial or managerial" efforts which produce profits after the investor has committed her funds.71 All promoters must put some efforts into packaging and marketing an investment plan. Howey's inquiry, though, applies after the sale is completed and asks whose efforts generate the expected profits-the promoter's efforts or the investor's efforts.

In McCown v Heidler, ${ }^{72}$ in which purchasers of undeveloped lots in a real estate development project filed securities claims, plaintiffs alleged that interests sold in real property were investment contracts. The court rejected this claim, concluding that the promoter's efforts in pricing the land and marketing it to potential investors were irrelevant. Only the promoter's promise of future efforts in the form of "substantial post-sale improvements" upon the land transformed the sale of an asset into an investment which could conceivably fall within the realm of the securities laws. ${ }^{73}$ In both brokered and non-brokered viatical settlements, expected profits are not the product of the seller's active efforts. With the completion of the assignment, the seller's participation is finished. As she does not contribute any post-sale entrepreneurial or managerial efforts, her activities do not satisfy the third prong of Howey.

Of equal importance, the seller's efforts also fail to satisfy Howey because her behavior actually hinders profit-realization. After the pricing and actual sale of the assignment, the existence or non-existence of the investor's profit will turn on the actual date of the seller's death. The sooner the death, the greater the rate of

\footnotetext{
32 Forman, 421 US at 852.

72527 F2d 204 (10th Cir 1975).

${ }^{73}$ Id at 211.
} 
return. Yet the seller is not attempting to die early, or even to die. On an abstract level, the seller has no economic incentive to die early. She has received a fixed price for the sale of her policy. She will receive no more or no less regardless of how long she lives. The counterargument that the value of the transfer to the seller decreases the longer she lives, because the same amount of assets must be spread out over a longer period of time, is theoretically correct but frivolous in terms of human behavior. There is no reason to believe that the seller does not share the almost universal human trait of preferring life to death. In fact, her actions in participating in the settlement are testament to her preference for life. The greatest value of viatical settlements to AIDS patients is that they provide needed resources for medical expenses. If the seller were interested in dying, she would forego medical treatment and allow her estate or her named beneficiary to realize the proceeds of the insurance policy, not an unrelated third party.

In non-brokered settlements, companies rely on no other person's efforts. Employing its own capital, the viatical settlement company acquires and retains all ownership rights in the policies it purchases, and eventually receives all of the life insurance proceeds. The only other party to the transaction is the seller. But the seller's efforts have already been eliminated from the pool of possible third-prong efforts. As the company is left without an "other" on whom to rely, non-brokered viatical settlements fail both the literal and the liberal interpretations of Howey's third prong.

In brokered transactions, the broker's efforts fail Howey's third prong because, like the seller's efforts, the broker's efforts are not post-sale managerial or entrepreneurial. In a brokered viatical settlement, the broker facilitates the transfer of ownership rights from the policyholder to independent investors. The broker itself never acquires or retains ownership rights. Instead, it simply matches a willing investor with a seller. Within this role the broker performs several important functions. The broker certifies the seller's medical condition both by gathering medical affidavits and records from the seller's physicians and by arranging for and reviewing an independent medical examination. Moreover, the broker prices the assignment of the seller's insurance policy. The potential investor is presented with a fixed purchase price predetermined by the broker. Whereas the price may or may not be negotiable, the bulk of the calculations have been performed by the broker, thereby relieving the buyer of the responsibility of acquiring and mastering the specialized medical, actuarial, and finan- 
cial information needed to assess a particular policy's market value. ${ }^{74}$

These efforts all end before the actual event of assignment. Once the life insurance policy has been assigned, the broker does not contribute any entrepreneurial or managerial efforts. Expected profits are not the product of the broker's active efforts. Like the sale of a plot of land, the investor simply sits and waits, hoping fortune will turn in her favor and she will receive the life insurance proceeds soon enough to earn at least a market rate of return. Obviously, the broker cannot influence this outcome. In fact, after the assignment is complete, the broker serves only the ministerial function of filing a timely claim with the insurance company upon the insured's death. As "ministerial" efforts do not satisfy either interpretation of Howey's third prong, ${ }^{75}$ brokered viatical settlements fail Howey's "solely from the efforts of others" requirement.

As stated earlier, an instrument must satisfy all elements of Howey to be a security. ${ }^{76}$ Because both brokered and non-brokered viatical settlements fail the third prong, Howey is not fulfilled. No further analysis is needed to conclude that viatical settlements are not securities. Nevertheless, an analysis of the fourth prong offers further reasons to conclude that viatical settlements are not securities.

2. Brokered viatical settlements under the fourth prong of Howey.

Howey's fourth requirement-the "common enterprise" test -complicates the analysis, not only because the circuit courts have articulated three interpretations of the requirement, but also because the requirement makes little sense when applied to the facts of viatical settlements. Nevertheless, the conclusion that necessarily follows from all interpretations is that viatical settlements do not satisfy the "common enterprise" test. The definition of a common enterprise under Howey has created much controversy. In Mordaunt $v$ Incomco, ${ }^{77}$ the Supreme Court declined an opportunity to resolve the dispute among the three competing interpretations of Howey's fourth prong, generally labelled "horizontal commonality," "broad vertical commonality," and "narrow vertical

\footnotetext{
54 Telephone interview with Richard Bandfield (cited in note 59).

is See Koscot, 497 F2d at 485.

78 See text accompanying note 52 .

77469 US 1115 (1985).
} 
commonality." "rs Since the controversy remains unresolved, this Comment will apply all three versions to viatical settlements.

Under horizontal commonality, a common enterprise is defined in terms of the relationship between individual investors. A common enterprise exists if investor funds are pooled together, usually with pro rata distribution of profits or losses. ${ }^{79}$ Both forms of vertical commonality, on the other hand, define a common enterprise in terms of the relationship between the individual investor and the promoter. Narrow vertical commonality demands that the success or failure of the investor mirror the success or failure of the promoter; their fortunes must rise and fall together. ${ }^{80}$ The broader form of vertical commonality requires only that the success or failure of the investor be dependent upon the efforts-rather than positively correlated with the profits-of the promoter. ${ }^{81}$

Brokered viatical settlements fail Howey's fourth prong under both narrow and broad vertical commonality. With regard to narrow commonality, because the broker earns a flat fee for services, regardless of whether the investment turns a profit, the success of the investor does not depend on the success of the promoter. The fates of the investor and the promoter thus do not rise and fall together; brokered settlements fail narrow commonality. Broad

${ }^{78}$ The Third, Sixth and Seventh Circuits have adopted horizontal commonality. The Fifth, Eighth, Tenth and Eleventh Circuits have adopted broad vertical commonality. Only the Ninth Circuit has adopted narrow vertical commonality. Comment, What is a Common Enterprise? A Question of Legislative Intent, 11 Miss Coll L Rev 125, 127-28 (1990).

${ }^{79}$ For endorsements of horizontal commonality, see Hirk $v$ Agri-Research Council, Inc., 561 F2d 96, 100-01 (7th Cir 1977) (discretionary futures trading account not an investment contract because of the absence of pooling); Curran v Merrill Lynch, Pierce, Fenner and Smith, 622 F2d 216, 222 (6th Cir 1980) (same); Salcer v Merrill Lynch, Pierce, Fenner and Smith, 682 F2d 459, 460 (3d Cir 1982) (same); Milnarik v M-S Commodities, Inc., 457 F2d 274, 276 (7th Cir 1972) (same); Deckebach v La Vida Charters, Inc. of Florida, 867 F2d 278, 281-83 (6th Cir 1989) (agreement between yacht purchasers and charter management firm not a security because there was no pooling of capital); Wasnowic $v$ Chicago Board of Trade, 352 F Supp 1066, 1069 (M D Pa 1972) (discretionary commodity trading account not a security absent pooling of funds); Poindexter v Merrill Lynch, Pierce, Fenner and Smith, 684 F Supp 478, 481 (E D Mich 1988) (same).

so For endorsements of this test, see Mordaunt $v$ Incomco, 686 F2d 815, 817 (9th Cir 1982) (discretionary commodities trading account not a security because there was no direct correlation between success of brokers and success of investment); Brodt v Bache \& Co., Inc., 595 F2d 459, 461 (9th Cir 1978) (same); Hector, 533 F2d at 433 (finding a genuine issue of material fact as to whether "fortunes" were sufficiently "interwoven" among a farmer, a feedlot, and a bank to constitute a common enterprise).

${ }^{81}$ For an endorsement of this test, see SEC $v$ Continental Commodities Corp., 497 F2d 516, 522 (5th Cir 1974), citing Koscot, 497 F2d 473 (finding that options on commodities futures contracts were securities because the investors' success depended on the promoter's expertise). 
commonality requires that the investor's success depend upon the promoter's efforts. Yet, as established under the analysis of Howey's third prong, ${ }^{82}$ the promoter has contributed no efforts recognized by Howey. Howey considers only those managerial and entrepreneurial efforts contributed by the promoter after the investor has committed her funds. ${ }^{83}$ Regardless of whether one identifies the promoter as the broker or the policy seller, neither contributes post-assignment efforts. As there are no promoter's efforts, the investor's success cannot depend on them. Brokered viatical settlements therefore satisfy neither narrow nor broad vertical commonality.

Brokered viatical settlements also fail to satisfy Howey's fourth prong under the horizontal commonality test. Horizontal commonality refers to the pooling of resources by a number of investors to promote a joint enterprise and usually requires a pro rata sharing of profits. ${ }^{84}$ Obviously, when one investor purchases all the ownership rights to a life insurance policy, there is no pooling. All the funds necessary for the investment came directly from her.

Even when several investors combine to purchase a single life insurance policy, the transaction lacks horizontal commonality. ${ }^{8}$ There is no pooling of funds in a joint enterprise from which the investors receive a pro rata sharing of profits. Howey recognizes the difference between the "nominal sale of property as a means of pooling money to be used in a common . . . enterprise" and actual asset sales. ${ }^{86}$ Only the former can fulfill the common enterprise requirement of Howey. In Howey, the Court realized that the sale of orange grove acreage and servicing contracts constituted more than "a fee simple interest in land. . . . The [companies] are offering an opportunity to contribute money and share in the profits of a large citrus fruit enterprise managed and partly owned by respondents. ... The resulting transfer of rights in land is purely incidental." ${ }^{\text {"gz }}$ Likewise, in Continental Marketing Corp. $v$ SEC ${ }^{88}$

\footnotetext{
S2 See text accompanying notes $64-76$.

s3 McCown, 527 F2d 204.

34 Deckebach, 867 F2d at 283; Stenger v R.H. Love Galleries, Inc., 741 F2d 144 (7th Cir 1984).

ss Even in such multiple purchases, all of the ownership rights of a particular policy are assigned at once. The assignment may be divided between several investors, but complete transfer is effected in one step. The seller does not, for example, assign 20 percent of the policy and then wait for the remaining 80 percent to be bought by other investors.

so Stenger, 741 F2d at 147 (finding no horizontal commonality in the sale of twelve paintings between the gallery owner and the purchaser).

87 Howey, 328 US at 299-300 (emphasis added).

ss 387 F2d 466 (10th Cir 1967).
} 
and Kemmerer $v$ Weaver, ${ }^{89}$ schemes involving beaver breeding were held to be securities because "the economic inducement was the faith or hope in the success of the enterprise-the domestic beaver industry - as a whole, and not the value of the animals alone." Agoin the sale of live beavers was a proxy for an ownership interest in a larger enterprise. The nominal asset was sold and the resulting monies were pooled to further the ongoing business from which profits would be derived.

In multiple-purchaser brokered viatical settlements, the sale of a fixed percentage interest of an insurance policy represents exactly what it purports to be. The buyer purchases an intangible asset (the future right to a specific amount of money) and expects to receive profits derived from the value of that asset-not from a larger enterprise for which the asset is employed. The fact that several investors purchase a fixed percentage of the same policy does not convert individual asset sales into a common pool of invested funds. Each investor forwards her money to buy title to a percentage of an insurance policy. The transfer of title of the insurance policy is the substance of the transaction. It is not incidental, and it is not a proxy for an ownership interest in a related enterprise. There is no larger, related enterprise; hence, there is no pooling. Brokered viatical settlements therefore do not satisfy a horizontal commonality requirement.

In summary, brokered viatical settlements easily fulfill the first two prongs of the Howey test but fail the third and fourth prongs of Howey. Brokered viatical settlements are not securities both because profits are not derived solely from the efforts of others and because a common enterprise as defined by Howey does not exist.

3. Non-brokered settlements under the fourth prong of Howey.

Finally, non-brokered viatical settlements do not fulfill any of the possible interpretations of Howey's fourth prong. First, there is no horizontal commonality because the buyer purchases the ownership rights of insurance policies using her own capital and, as of the date of this writing, holds the policies until maturity. ${ }^{91}$ Like the case of the sole investor in a brokered settlement, only one per-

89 445 F2d 76 (7th Cir 1971).

so Continental Marketing, $387 \mathrm{~F} 2 \mathrm{~d}$ at 471.

21 Telephone interview with Richard Bandfield (cited in note 59). 
son contributes capital. Whether the "person" is a natural person, a partnership, or a corporation does not alter the conclusion that there is no pooling of funds. Any intermingling of funds in a partnership or a corporation occurs at the stage of corporate or partnership formation, not when the entity purchases an asset like a life insurance policy.

Nor is there vertical commonality between buyer and seller in a non-brokered viatical settlement. Both the broad and narrow vertical commonality tests rely on distinctions between investor and promoter that make no sense in the context of a non-brokered settlement. In non-brokered viatical settlements, the identity of the promoter is unclear.

The purchaser cannot be the promoter because she is already the investor. Both narrow and broad vertical commonality presume the existence of two distinct, separate parties playing the roles of promoter and investor. The tests ask what the relationship is between promoter and investor, not whether there is a separation of identity between promoter and investor. The rationale for this rule lies within the purpose of the '33 Act.

The federal securities laws protect investors from fraud. ${ }^{92}$ The laws protect investors in part by requiring disclosure of information to the market. The bargaining imbalances of large-scale national or even regional securities markets render the individual one of a multitude of fungible investors. Without the securities laws, the individual cannot, in practice, force disclosure of the necessary information as a condition of investing her money..$^{93}$ The securities laws mitigate this bargaining imbalance by mandating information disclosure by issuing companies. Obviously, these concerns have no application if the promoter and buyer are the same entity.

In non-brokered transactions, the only other candidate for promoter is the seller, but the seller makes an awkward promoter because the seller has little of the undisclosed information ${ }^{94}$ and

\footnotetext{
"2 Ernst \& Ernst v Hochfelder, 425 US 185, 195 (1976) ("The Securities Act of 1933 ... was designed . . . to protect investors against fraud.").

93 SEC v Ralston Purina Co., 346 US 119, 124 (1953) ("The design of the statute is to protect investors by promoting full disclosure of information thought necessary to informed investment decisions."). See also James D. Gordon III, Common Enterprise and Multiple Investors: $A$ Contractual Theory for Defining Investment Contracts and Notes, 3 Colum Bus L Rev 635, 659 (1988); Frank Easterbrook, Lecture at the University of Chicago Law School (Jan 14, 1993). Similarly, the private offering exemption is limited by the idea that the offerees must be "provided with or given access to the information that is material to their investment decision." SEC v Murphy, 626 F2d 633, 643 (9th Cir 1980).

24 The buying company will need access to some (mainly medical) information concerning the seller, but the one-on-one bargaining process pressures the seller to reveal the infor-
} 
financial concerns typical of a promoter. With regard to information disclosure, the investor normally looks to the securities laws to prompt the promoter to disclose financial records, past dealings, and whatever other information she believes is relevant to her investment decision. Here, the only relevant information to disclose is the existence of a particular life insurance policy, the solvency of the insurance company, and the certification of the seller's medical condition. Although this information demands verification for an informed investment decision, the seller is no more equipped to evaluate the financial state of an insurance company than the SEC is equipped to evaluate medical information. Requiring disclosure by the seller-as-promoter could, in fact, frustrate the purposes of the '33 Act by incorrectly signalling to investors that the disclosed information has been approved by competent, qualified examiners, thereby inducing unwarranted reliance by the investor.

With regard to the seller's financial concerns, the seller does not expect to realize a profit through an ongoing enterprise or a future investment. Instead, she wants to liquidate an asset to gain funds for personal consumption. As such, her interest is limited to (1) policing for what she might feel is an excessively discounted offering price, and (2) attempting to negotiate for the highest possible sale price. ${ }^{95}$ She seeks the highest price on the final sale of an asset, not profits from a future ongoing business or financial activity. As only the latter profit motive is applicable in the securities context, ${ }^{96}$ the seller does not have a profit motive in any sense that is relevant to a Howey determination. Her actions are simply an assignment of a life insurance policy. The fact that other people are employing the assignment as a speculative, profit-seeking investment does not alter or relate back to her actions. Because the seller is not offering a security, she cannot be the promoter of a security.

More importantly, there can be no promoter because there is nothing to promote. As stated above, the seller is liquidating an asset. She is not creating an ongoing venture and is not expecting future profits from continued investment strategies or productive

mation. Since the buyer has the power to obtain necessary information when negotiating with the seller, disclosure will occur independently of the securities laws.

${ }^{\text {as }}$ It would be difficult for the seller to increase the value of her policy by misrepresenting the seriousness of her illness. Viatical settlement purchasers protect themselves from fraud by requiring thorough, independent medical reviews and objective test criteria, such as t-cell counts. See Bandfield, Viatical Settlements at 9 (cited in note 1).

${ }^{98}$ Howey's "common enterprise" and profits "solely from the efforts of others" requirements indicate that the Act applies to investments in a future business or activity. 
enterprises. Likewise, the buyer is purchasing an asset. Her purchase of an interest in an insurance policy (be it complete or partial) is not a nominal title transfer facilitating investment in a productive enterprise. There is no enterprise in which to invest. There is only an asset to transfer, and all parties are engaged only in asset-transferral. As there is no ongoing investment or enterprise to promote, there can be no promoter. Non-brokered viatical settlements therefore fail to meet the requirement of either narrow or broad vertical commonality under the fourth prong of the Howey test.

To summarize, non-brokered viatical settlements fail the Howey investment contract test. Because the settlement company performs all necessary tasks on its own behalf, non-brokered settlements violate Howey's requirement that all profits derive "solely from the efforts of others." Moreover, non-brokered settlements fail under the vertical commonality version of the common enterprise requirement because of the commonality and exclusivity of identity between investor and promoter. They also fail to satisfy the specific requirements of a horizontal commonality test, because only one investor purchases the policy.

\section{Functional Analysis of Viatical Settlements as Securities}

Howey articulates the authoritative test for determining if unorthodox or innovative investments like viatical settlements are securities. Nonetheless, it is not the only or even the most relevant means of analysis. When applying the test, courts must not lose sight of their underlying purpose: To further the ends of the securities laws. Courts must determine which transactions fit within the federal securities laws; when doing so they should not be "bound by legal formalism, but instead [should] take account of the economics of the transaction under investigation." "term 'investment contract' [as] a catch-all to bring within the securities acts interests that have the functional attributes of stock and other formal securities but are not so denominated."98 Therefore, this Comment supplements the Howey analysis with a functional analysis, probing directly what the Howey analysis probed indirectly. Recognizing the value of direct inquiry, the Supreme Court in Variable Annuity and United Benefit employed func-

${ }^{97}$ Reves v Ernst \& Young, 494 US 56, 61 (1990).

93 Peoria Union Stock Yards Co. Retirement Plan v Penn Mut. Life Ins. Co., 698 F2d 320, 324 (7th Cir 1983). 
tional analysis to determine if particular annuities fell within the $\S 3(a)(8)$ exemption of the '33 Act. ${ }^{99}$ Applying the same functional analysis to viatical settlements reaffirms this Comment's analysis under Howey.

A functional analysis should begin with an understanding of what differentiates a security from other profit-seeking investments. Why is a purchase of a share of stock a security whereas the purchase of an empty plot of land with an eye towards the land's future appreciation not a security? These cases might be distinguished by focusing on the purposes for which the invested funds are sought.

The purpose which differentiates securities from other profitseeking investments is capital formation. "[T]he focus of the [securities] Acts is on the capital market of the enterprise system: the sale of securities to raise capital for profit-making purposes." $100 \mathrm{Se}-$ curities are unique among investments in that they participate in the process of creating and nurturing entepreneurial activity. ${ }^{101}$ Capital formation is active: building, supporting, and expanding the market as it creates more potential capital through the profit mechanism. ${ }^{102}$ Other investment strategies, such as real estate investments or artwork, are passive: they add nothing to the productive process but derive their value from external events and signals. They sit inert-isolated and removed from the stream of financial activity. They enter the stream only for title transfers or similar formal transactions. As such, they are mechanisms for wealth accumulation and transfer, but not for production or growth.

The '33 Act therefore protects not only the individual investor against fraud in the capital marketplace but it also protects the integrity and functioning of the capital marketplace itself, by encouraging a steady, unhampered flow of funds into the market. Thus, in the 1982 amendments to the '33 Act, Congress stated that it acted to protect "capital formation in the form of investments in

99 See Section II.B.

100 Forman, 421 US at 849.

101 Of course, capital can also be raised through mechanisms such as personal and family savings and through loans from financial or government institutions.

${ }^{102}$ In Howey, the Court noted that, prior to the Act, state courts defined an "investment contract" as a "contract or scheme for the "placing of capital or laying out of money in a way intended to secure income or profit from its employment.' " 328 US at 298, quoting State v Gopher Tire and Rubber Co., 146 Minn 52, 56, 177 NW 937, 938 (1920) (emphasis added). 
the U.S. securities markets." "Thes The amendments advanced the '33 Act's original objectives: "protecting public investors, assuring market integrity, and, most important, restoring investor confidence in order to attract needed funds back into the U.S. capital markets." 104 Given the '33 Act's goal of protecting capital formation and capital markets, the '33 Act's regulatory bounds logically extend only to those profit-seeking investments that contribute to capital formation. ${ }^{105}$

Viatical settlements do not contribute to capital formation. As stated earlier, the investor transfers funds to the seller, who uses them for personal consumption, not capital formation. Whereas new capital is formed by a process of accretion, in which funds are accumulated until they reach a productive mass, viatical settlements contribute to consumption, which actually dissipates the transferred money. The transaction does not fund further productive financial activity. The cycle begins and ends with the transfer to the policyholder.

This analysis reaffirms the determination reached under Howey that viatical settlements are not securities. More importantly, it helps to explain the strains that became apparent in applying Howey to viatical settlements. Viatical settlements do not fit neatly into the pre-defined categories of Howey because they do not serve the same purpose as securities. Howey, though, never directly examines the purpose of the transaction. It instead focuses on manifestations of the underlying security characteristics. Although viatical settlements share some of a security's features-investment of money, expectation of profits, at times forms of vertical commonality-they do not function as tools of capital formation. " $[\mathrm{A}]$ thing may be within the letter of the statute and yet not within the statute, because not within its spirit, nor within

${ }^{103}$ Clarifying the Jurisdiction of the Securities and Exchange Commission and the Definition of Security, HR Rep No 97-626(I), 97th Cong, 2d Sess 2 (1982).

${ }^{104}$ Id at 3 (emphasis added).

108 Courts read this emphasis on capital formation into the Act, limiting the "any note" language in the definition of a security to investment, as opposed to commercial, paper. Courts treat a note issued for investment purposes as a security, whereas a note issued for commercial or consumer purposes is not considered a security. See Bellah v First National Bank of Hereford, 495 F2d 1109, 1113 (5th Cir 1974) (applying distinction between commercial paper and investment paper); Zabriskie $v$ Lewis, 507 F2d 546, 551-52 (10th Cir 1974) (holding that notes given "not for a consumer purpose but rather" to promote a corporation were securities). Although ultimately the Supreme Court in Reves did not adopt the "investment versus commercial" purpose test, it did conclude that a note "exchanged to facilitate .. . [a] commercial or consumer purpose" was less sensibly described as a security. 494 US at 66 . 
the intention of its makers." ${ }^{106}$ Even if viatical settlements had superficially met the requirements of Howey, such superficial overlap would not alter their fundamental nature and render them securities. "[F]orm should be disregarded for substance and the emphasis should be on economic reality." ${ }^{107}$ In this instance, the Howey test's goal of divining substance through form succeeds. However, its strained and awkward application suggests that a more appropriate and insightful analysis is found through a functional examination. ${ }^{108}$

\section{Conclusion}

Viatical settlements are not securities subject to the regulatory control of the Securities Act of 1933. Although not eligible for exemption as $\S 3(\mathrm{a})(8)$ insurance products, they do not fall within $\S 2(1)$ 's definition of a security because they fail to satisfy all four prongs of the Howey test. Moreover, substance must prevail over form, and viatical settlements are similar in form, but not in substance, to securities. Viatical settlements play no role in capital markets or capital formation. Therefore, they cannot be securities.

${ }^{108}$ Forman, 421 US at 849, quoting Church of the Holy Trinity $v$ United States, 143 US 457,459 (1892).

${ }_{107}$ Tcherepnin $v$ Knight, 389 US 332, 336 (1967); see also Reves, 494 US at 61 (when determining which transactions fit within the coverage of the securities laws, federal courts are "not bound by legal formalisms, but instead take account of the economics of the transaction under investigation"); Matek v Murat, 862 F2d 720, 724 (9th Cir 1988) (same).

${ }^{108}$ Another factor which may in the future militate against securities regulation of viatical settlements is the existence of an alternate regulatory regime which sufficiently protects investors' concerns. In Marine Bank v Weaver, 455 US 551, 559 (1982), the Supreme Court declined to find a certificate of deposit covered "under the antifraud provisions of the federal securities laws since the holders of bank certificates of deposit are abundantly protected under the federal banking laws." See also R.J. Wolf v Banco Nacional de Mexico, S.A., 739 F2d 1458, 1464 (9th Cir 1984) (declining to find certificates of deposit for pesos to be securities due to the existence of American and Mexican bank regulatory structures). At present, only a handful of states regulate the viatical settlement industry and, of those, only California requires licensing of viatical settlement companies. Dan Levy, Terminally Sick May Cash in Life Insurance: California is First State to License "Living Benefits," San Fran Chronicle A1 (Apr 13, 1993). But if more states follow California's lead, federal securities regulation may be unnecessary due to the existence of alternate consumer protection. Such protection would, in fact, be preferable to securities regulation. Not only would it address the specific concerns involved with viatical settlements, thereby eliminating the current incompatibility of securities regulation concerns with viatical settlements, but the regulations would also address the concerns of viatical settlement sellers. California, for example, mandates the confidentiality of patient medical records, a concern not addressed in the securities laws. 